\title{
Control of Downy Brome on Nebraska Range-
}

land

\section{A. MORROW, C. R. FENSTER, AND M. K. MCCARTY}

Highlight: Experiments to study the control of downy brome were conducted at three locations on Nebraska rangeland. Soils ranged from a silty clay loam to a loamy sand. Herbicide treatments included atrazine, cyanazine, metribuzin, and simazine at 0.5 and $1.0 \mathrm{lb} / \mathrm{acre}$; glyphosate and terbacil at 0.25 and 0.5 $\mathrm{b} /$ acre; secbumeton at 1.0 and $2.0 \mathrm{lb} / \mathrm{acre}$; and paraquat at 0.25 $\mathrm{lb} /$ acre applied in the spring. All treatments, with the exceptions of glyphosate and paraquat, were also applied in the fall. Metribuzin at $0.33 \mathrm{lb} /$ acre was also applied in the fall. Atrazine, metribuzin, and simazine effectively controlled downy brome. Downy brome control and forage production were greater when these herbicides were applied in the spring. Forage production was not significantly increased when herbicides were applied in the fall, but the trend was toward increased production. Injury to perennial cool-season forage grasses was greater from springapplied herbicides than from fall applications. Control of downy brome was greater on fine-textured soils than on coarse-textured soils.

Downy brome (Bromus tectorum L.) was introduced to the arid and semiarid western United States about 1900 and has become a major portion of the cover on grazing lands in that area (Stewart and Hull 1949). It has forage value in its immature stages, but production fluctuates greatly with moisture conditions. Downy brome is a prolific seed producer and spreads rapidly. Seeds will germinate and plants emerge when conditions are favorable, whether in the fall, during the winter, or in the early spring (Hull and Hansen 1974). Large numbers of viable seeds are carried over from one year to the next in litter and soil (Young et al. 1969; Hull and Hansen 1974), but germination of downy brome seeds after that period of time is very low (Hulbert 1955). Downy brome seed production is density-dependent and seed can be environmentally conditioned to continuous germination (Young et al. 1969); however, complete germination in a single season under natural conditions is rare (Hull and Hansen 1974). Competition from downy brome can be reduced if seed production can be prevented.

Weed growth and establishment of replacement vegetation are directly related to soil moisture and temperatures in the immediate environment of the growing plants (Evans et al. 1970). More soil moisture is available to perennial grass seedlings where weeds such as downy brome are controlled.

\footnotetext{
Morrow and McCarty are research agronomists, Agricultural Research Service, U.S Department of Agriculture, Mandan, North Dakota and Lincoln, Nebraska, respectively Fenster is district extension agronomist, University of Nebraska, Panhandle Station Scottsbluff.

The report is a contribution of Agr. Res. Serv., North Central Region, U.S. Dep. Agr., and Nebraska Agricultural Experiment Station (paper no. 5108).

Manuscript received August 23, 1976.
}

Rydrych (1974) in Oregon found that downy brome emerging with winter wheat was most competitive during March. On a silt loam soil receiving $42 \mathrm{~cm}$ (16.5 inches) of precipitation annually, downy brome densities of 108 to 160 plants per $\mathrm{m}^{2}(10$ to 15 plants per $\mathrm{ft}^{2}$ ) lowered wheat (Triticum aestivum $\mathrm{L}$. 'Gaines') yields by only $6 \%$ when controlled by March. A reduction of $40 \%$ resulted when the competition from downy brome was not removed until wheat harvest.

Several herbicides are presently available that will control annual weeds such as downy brome. Kapusta and Strieker (1975) in Illinois found that cyanazine [2-[[4-chloro-6(ethylamino)-s-triazin-2-yl] amino]-2-methlpropionitrile] at 3.4 $\mathrm{kg} / \mathrm{ha}(3 \mathrm{lb} / \mathrm{acre})$, paraquat (1,1'-dimethyl-4,4'-bipyridinium ion) at $0.56 \mathrm{~kg} / \mathrm{ha}(0.5 \mathrm{lb} / \mathrm{acre})$, pronamide [3,5-dichloro $(N-1,1$ dimethyl-2-propynyl)benzamide] at 0.84 and $1.4 \mathrm{~kg} / \mathrm{ha}(0.75$ and $1.25 \mathrm{lb} /$ acre), simazine [2-chloro-r,6-bis(ethylamino)-striazine] at $1.12 \mathrm{~kg} / \mathrm{ha}(1.0 \mathrm{lb} / \mathrm{acre})$, and terbacil (3-tert-butyl-5chloro-6-methyluracil) at $0.84 \mathrm{~kg} / \mathrm{ha}(0.75 \mathrm{lb} /$ acre $)$ resulted in excellent control of downy brome in alfalfa (Medicago sativa L.) when applied when the alfalfa and downy brome were dormant. There was no injury to the alfalfa and yield increases were associated with downy brome control.

Eckert et al. (1974), in an evaluation of the atrazine-fallow technique, fund that 0.6 to $1.2 \mathrm{lb} /$ acre of atrazine [2-chloro-4(ethylamino)-6-(isopropylamino)-s-triazine] applicd in the fall effectively controlled annual weeds. Only the $1.2 \mathrm{lb} /$ acre rate of atrazine damaged perennial grass seedlings. More research is needed in determining the effect of atrazine on established perennial grasses.

The objectives of this study were to evaluate several herbicides for the control of downy brome and to determine the effect of downy brome on perennial forage grass production.

\section{Materials and Methods}

Experiments were established for the control of downy brome at three locations in Nebraska: northwestern Nebraska on a silty clay loam soil receiving 13 inches annual precipitation; north central Nebraska on a loamy sand soil receiving 21 inches annual precipitation; and western Nebraska on a silt loam soil receiving 15 inches annual precipitation. Spring and fall herbicide treatments were applied at the north central and northwestern locations; spring treatments were applied at the western location.

Spring treatments were applied in early March and fall treatments were applied in November. Treatments were applied one time in each experiment. Herbicide treatments included atrazine, cyanazine, and simazine at 0.5 and $1.0 \mathrm{lb} /$ acre; secbumeton [ $\mathrm{N}$-ethyl-6-methoxy-N' (1methylpropyl) 1,3,5-triazine-2, 4-diamine] at 1 and $2 \mathrm{lb} /$ acre, metribuzin [4-amino-6-tert-butyl-3-(methylthio)-as-triazine-5(4H-one] at $0.33,0.5$, and $1.0 \mathrm{lb} /$ acre and terbacil at 0.25 and $0.5 \mathrm{lb} /$ acre. Paraquat 
at 0.25 and glyphosate [ $N$-(phosphonomethyl)glycine] at 0.25 and $0.50 \mathrm{lb} /$ acre were also included in spring treatments at the north central and northwestern locations.

The experimental design was a randomized complete block with four replications. Plot size was 10 by $35 \mathrm{ft}$. Herbicides were applied with a tractor-mounted constant-pressure sprayer in a total volume of $20 \mathrm{gal} / \mathrm{acre}$ at $32 \mathrm{psi}$. Percentage of downy brome control was visually estimated the year of application and 1 and 2 years following application. The fall-applied treatments were not evaluated the year of application. Forage yields were determined by clipping at a 2 -inch height the year of application and the year following application of spring-applied treatments, and the year following fall application of herbicides. An area 3 by $28 \mathrm{ft}$ was harvested in each plot. The harvested forage was oven-dried at $140^{\circ} \mathrm{F}$ for 48 hours. No forage yields were determined from the loamy sand soil location because of the lack of moisture and control over grazing livestock. Primary forage species were western wheatgrass (Agropyron smithii Rydb.) and blue grama [Bouteloua gracilis (H.B.K.) Lag. ex Steud.]. Other forage species include sideoats grama [Bouteloua curtipendula (Michx.) Torr.], prairie sandreed [Calamovilfa longifolia (Hook.) Scribn.], needleandthread (Stipa comata Trin. and Rupr.), prairie Junegrass [Koeleria cristata (L.) Pers.], and sand dropseed [Sporobolus cryptandrus (Torr.) A. Gray]. The primary weedy grass was downy brome. Sixweeks fescue (Festuca octoflora Walt.) was also present. Broadleaf plants were of minor consequence in the study area.

\section{Results and Discussion}

Herbicides applied on the silty clay loam soil in the spring resulted in excellent control of downy brome at 2 months after application (Table 1). All treatments except cyanazine at 0.5 $\mathrm{lb} /$ acre and paraquat at $0.25 \mathrm{lb} /$ acre resulted in $95 \%$ or more control at this time. Five months after application, glyphosate and paraquat had lost their effectiveness, and the effect of cyanazine at $0.5 \mathrm{lb} /$ acre had decreased to $40 \%$. The effect of simazine at $0.5 \mathrm{lb} /$ acre decreased from $98 \%$ to $78 \% 5$ months after application, but all other treatments effectively controlled downy brome. Glyphosate and paraquat had effectively controlled emerged downy brome at the time of application, but did not affect later emerging plants or plants arising from seed sources out of the plot area.

Herbicide applications in the spring on the loamy sand soil were not as effective as those applied to the fine-textured soil. Three months after application, atrazine at 0.5 and $1.0 \mathrm{lb} /$ acre controlled 55 and $78 \%$, respectively, of the downy brome. Only
Table 2. Downy brome control (\%) following fall application of several herbicides on two soil types of Nebraska rangeland. ${ }^{1}$

\begin{tabular}{|c|c|c|c|c|}
\hline \multirow{2}{*}{\multicolumn{2}{|c|}{ Treatment }} & \multicolumn{2}{|c|}{ Silty clay loam } & \multirow{3}{*}{$\begin{array}{l}\text { Loamy sand } \\
7 \text { mo. after } \\
\text { application }\end{array}$} \\
\hline & & \multirow{2}{*}{$\begin{array}{l}8 \mathrm{mo} \text {. after } \\
\text { application }\end{array}$} & \multirow{2}{*}{$\begin{array}{l}20 \text { mo. after } \\
\text { application }\end{array}$} & \\
\hline Herbicide & Rate (lb/acre) & & & \\
\hline Check & - & $0 \mathbf{a}$ & $0 \mathrm{a}$ & $0 \mathrm{a}$ \\
\hline Atrazine & 0.5 & $75 \mathrm{de}$ & $80 \mathrm{~cd}$ & $68 \mathrm{~d}$ \\
\hline Atrazine & 1.0 & $100 \mathrm{f}$ & $85 \mathrm{~cd}$ & $89 \mathrm{ef}$ \\
\hline Cyanazine & 0.5 & $40 \mathrm{~b}$ & $12 \mathrm{ab}$ & $2 \mathrm{a}$ \\
\hline Cyanazine & 1.0 & $50 \mathrm{bc}$ & $42 b c$ & $18 \mathrm{abc}$ \\
\hline Secbumeton & 1.0 & $42 b$ & $22 \mathrm{ab}$ & $5 \mathrm{ab}$ \\
\hline Secbumeton & 2.0 & $98 \mathrm{f}$ & $82 \mathrm{~cd}$ & $28 \mathrm{c}$ \\
\hline Metribuzin & 0.33 & $68 \mathrm{~cd}$ & $45 \mathrm{bc}$ & $35 \mathrm{c}$ \\
\hline Metribuzin & 0.5 & $90 \mathrm{ef}$ & $78 \mathrm{~cd}$ & $78 \mathrm{de}$ \\
\hline Metribuzin & 1.0 & $95 f$ & $95 d$ & $100 \mathrm{f}$ \\
\hline Simazine & 0.5 & $68 \mathrm{~cd}$ & $52 \mathrm{bc}$ & $22 \mathrm{bc}$ \\
\hline Simazine & 1.0 & $98 \mathrm{f}$ & $75 \mathrm{~cd}$ & $68 \mathrm{~d}$ \\
\hline Terbacil & 0.25 & $58 \mathrm{bcd}$ & $80 \mathrm{~cd}$ & $75 \mathrm{de}$ \\
\hline Terbacil & 0.5 & $98 \mathrm{f}$ & $72 \mathrm{~cd}$ & $99 \mathrm{f}$ \\
\hline
\end{tabular}

Means in the same column followed by the same letter do not differ significantly at the $5 \%$ level by Duncan's multiple range test.

metribuzin at 0.5 and $1.0 \mathrm{lb} /$ acre and terbacil at 0.25 and $0.5 \mathrm{lb} /$ acre resulted in more than an $85 \%$ stand reduction of downy brome. Metribuzin at $0.5 \mathrm{lb} /$ acre resulted in a stand reduction of $88 \%$, while the $1.0 \mathrm{lb} /$ acre rate controlled $98 \%$ of the downy brome. Terbacil at 0.25 and $0.5 \mathrm{lb} /$ acre resulted in 85 and $95 \%$ downy brome control, when evaluated 3 months after application. The differences in effectiveness between herbicides applied to the silty clay loam soil and the loamy sand soil are apparently related to the soil texture, organic matter content and amount of annual precipitation. Precipitation was below normal during the years these experiments were conducted.

Of the herbicides applied in the spring on the silt loam soil, only atrazine at $1 \mathrm{lb} / \mathrm{acre}$, metribuzin at all rates, and terbacil at $0.5 \mathrm{lb} /$ acre reduced the stand of downy brome by more than $80 \%$. All other treatments were less than $70 \%$ effective when evaluated 5 months after application. Terbacil at $0.5 \mathrm{lb} /$ acre and metribuzin at $1.0 \mathrm{lb} /$ acre gave nearly complete control the year of application. Metribuzin at 0.33 and $0.5 \mathrm{lb} /$ acre resulted in 88 and $83 \%$ control, respectively, of the stand of downy brome during the year of application.

Fall application of herbicides on the silty clay loam soil was generally not as effective for the control of downy brome as

Table 1. Downy brome control (\%) following spring application of several herbicides on three soil types of Nebraska rangeland. ${ }^{1}$

\begin{tabular}{|c|c|c|c|c|c|}
\hline \multirow[b]{3}{*}{ Herbicide } & \multirow{3}{*}{$\begin{array}{l}\text { Treatment } \\
\text { Rate (lb/acre) }\end{array}$} & \multicolumn{2}{|c|}{ Silty clay loam } & \multirow{3}{*}{$\begin{array}{l}\text { Loamy sand } \\
3 \text { mo. after } \\
\text { application }\end{array}$} & \multirow{3}{*}{$\begin{array}{c}\text { Silt loam } \\
5 \text { mo. after } \\
\text { application }\end{array}$} \\
\hline & & \multirow{2}{*}{$\begin{array}{l}2 \text { mo. after } \\
\text { application }\end{array}$} & \multirow{2}{*}{$\begin{array}{l}5 \text { mo. after } \\
\text { application }\end{array}$} & & \\
\hline & & & & & \\
\hline Check & - & $0 \mathrm{a}$ & $0 \mathrm{a}$ & $0 \mathrm{a}$ & $0 \mathrm{a}$ \\
\hline Atrazine & 0.5 & $100 \mathrm{~d}$ & $98 d$ & $55 \mathrm{~d}$ & $55 \mathrm{~cd}$ \\
\hline Atrazine & 1.0 & $98 \mathrm{~d}$ & $92 \mathrm{~cd}$ & $78 \mathrm{e}$ & $88 \mathrm{f}$ \\
\hline Cyanazine & 0.5 & $72 \mathrm{~b}$ & $40 \mathrm{~b}$ & $12 \mathrm{abc}$ & $43 \mathrm{bc}$ \\
\hline Cyanazine & 1.0 & $95 \mathrm{~cd}$ & $95 \mathrm{~cd}$ & $45 \mathrm{~cd}$ & $68 \mathrm{de}$ \\
\hline Glyphosate & 0.25 & $98 \mathrm{~d}$ & $8 \mathrm{a}$ & $15 \mathrm{abc}$ & \\
\hline Glyphosate & 0.5 & $98 \mathrm{~d}$ & $0 \mathrm{a}$ & $20 \mathrm{abc}$ & \\
\hline Secbumeton & 1.0 & $95 \mathrm{~cd}$ & $88 \mathrm{~cd}$ & $0 \mathrm{a}$ & $58 \mathrm{~cd}$ \\
\hline Secbumcton & 2.0 & $100 \mathrm{~d}$ & $100 \mathrm{~d}$ & $28 \mathrm{bc}$ & $68 \mathrm{de}$ \\
\hline Metribuzin & 0.33 & & & & $88 \mathrm{f}$ \\
\hline Metribuzin & 0.5 & $100 \mathrm{~d}$ & $100 \mathrm{~d}$ & $88 \mathrm{e}$ & $83 \mathrm{ef}$ \\
\hline Metribuzin & 1.0 & $100 \mathrm{~d}$ & $95 \mathrm{~cd}$ & $98 \mathrm{e}$ & $100 \mathrm{f}$ \\
\hline Paraquat & 0.25 & $85 c$ & $0 \mathrm{a}$ & $5 \mathrm{ab}$ & \\
\hline Simazine & 0.5 & $98 \mathrm{~d}$ & $78 \mathrm{c}$ & $28 \mathrm{bc}$ & $10 a$ \\
\hline Simazine & 1.0 & $100 \mathrm{~d}$ & $98 \mathrm{~d}$ & $30 \mathrm{~cd}$ & $43 b c$ \\
\hline Terbacil & 0.25 & $98 \mathrm{~d}$ & $95 \mathrm{~cd}$ & $85 \mathrm{c}$ & $30 \mathrm{~b}$ \\
\hline Terbacil & 0.5 & $98 \mathrm{~d}$ & $100 d$ & $95 \mathrm{e}$ & $98 \mathrm{f}$ \\
\hline
\end{tabular}

${ }^{1}$ Means in the same column followed by the same letter do not differ significantly at the 5\% level by Duncan's multiple range test. 
spring application (Table 2). Eight months after application, atrazine, metribuzin and simazine at $1.0 \mathrm{lb} / \mathrm{acre}$, secbumeton at $2.0 \mathrm{lb} / \mathrm{acre}$, and terbacil at $0.5 \mathrm{lb} /$ acre resulted in more than $95 \%$ stand reduction of downy brome, while metribuzin at 0.5 $\mathrm{lb} /$ acre resulted in $90 \%$ downy brome control. Atrazine at $0.5 \mathrm{lb} /$ acre gave $75 \%$ control. Twenty months after application, most herbicides had decreased in effectiveness, as would be expected. There was no difference between rates of atrazine 20 months after application, each rate resulting in about $80 \%$ control of downy brome. The $2.0 \mathrm{lb} /$ acre rate of secbumeton still achieved $82 \%$ control, while $0.5 \mathrm{lb} /$ acre of metribuzin controlled $78 \%$ of the stand of downy brome. Metribuzin at 1.0 $\mathrm{Ib} /$ acre reduced the stand of downy brome by $95 \%, 20$ months after application. There was no difference between rates of terbacil: 0.25 and $0.5 \mathrm{lb} /$ acre rates resulted in 80 to $72 \%$, respectively. Atrazine or simazine at $1.0 \mathrm{lb} /$ acre applied in the fall to a silty clay loam soil receiving about 13 inches annual precipitation appears to be an effective treatment for the control of downy brome.

Fall applications of herbicides on a loamy sand soil responded slightly differently than those applied to the fine-textured soil. Seven months after application, all treatments, except both rates of cyanazine and secbumeton at $1.0 \mathrm{lb} / \mathrm{acre}$, resulted in a statistically significant stand reduction of downy brome. However, only atrazine and metribuzin at 0.5 and $1.0 \mathrm{lb} / \mathrm{acre}$, simazine at $1.0 \mathrm{lb} / \mathrm{acre}$, and terbacil at both rates resulted in downy brome control of more than $65 \%$ when compared to the untreated plots. Atrazine at $0.5 \mathrm{lb} /$ acre and simazine at $1.0 \mathrm{lb} /$ acre resulted in $68 \%$ control of downy brome, while $1.0 \mathrm{lb} /$ acre of atrazine reduced the stand of downy brome by $89 \%$. Metribuzin at $0.5 \mathrm{lb} /$ acre gave $78 \%$ control, while $1.0 \mathrm{lb} /$ acre resulted in complete control of downy brome. Terbacil at 0.25 $\mathrm{lb} /$ acre gave $75 \%$ control and $0.5 \mathrm{lb} /$ acre resulted in $99 \%$ downy brome control. These data indicate that the most promising herbicide for the control of downy brome growing on a loamy sand soil receiving about 21 inches precipitation would appear to be atrazine at a rate of $1.0 \mathrm{lb} / \mathrm{acre}$ applied in the fall. The other effective herbicides are too high in cost to be considered at this point

Herbicides applied to a silt loam soil in the spring decreased in effectiveness the year following application, with the exception of secbumeton at $2.0 \mathrm{lb} /$ acre (Table 3 ). Downy brome

Table 3. Downy brome control (\%), downy brome and forage production (lb/acre, oven-dry) 17 months after application of herbicides in the spring on a silt loam soil of Nebraska rangeland. ${ }^{\prime}$

\begin{tabular}{|c|c|c|c|c|}
\hline \multicolumn{2}{|c|}{ Treatment } & \multirow{2}{*}{$\begin{array}{c}\text { Downy brome } \\
\text { control }\end{array}$} & \multirow{2}{*}{$\begin{array}{c}\text { Forage } \\
\text { production }\end{array}$} & \multirow{2}{*}{$\begin{array}{c}\text { Downy brome } \\
\text { production }\end{array}$} \\
\hline Herbicide & Rate (lb/acre) & & & \\
\hline Check & - & $0 a$ & $540 a$ & $410 d$ \\
\hline Atrazine & 0.5 & 31 bcdef & $885 \mathrm{ab}$ & $255 \mathrm{bcd}$ \\
\hline Atrazine & 1.0 & $49 \mathrm{fg}$ & $745 \mathrm{ab}$ & $65 \mathrm{ab}$ \\
\hline Cyanazine & 0.5 & 41 defg & $915 \mathrm{ab}$ & $190 \mathrm{abc}$ \\
\hline Cyanazine & 1.0 & 22 bcd & $750 a b$ & $310 \mathrm{~cd}$ \\
\hline Secbumeton & 1.0 & $58 \mathrm{~g}$ & $730 a b$ & $20 a$ \\
\hline Secbumeton & 2.0 & $86 \mathrm{~h}$ & $545 \mathrm{a}$ & $30 a$ \\
\hline Metribuzin & 0.33 & $20 \mathrm{bc}$ & $970 a b$ & $115 \mathrm{ab}$ \\
\hline Metribuzin & 0.5 & 28 bcde & $845 a b$ & $190 \mathrm{abc}$ \\
\hline Metribuzin & 1.0 & 40 cdefg & $965 \mathrm{ab}$ & $70 a b$ \\
\hline Simazine & 0.5 & $20 \mathrm{bc}$ & $680 \mathrm{ab}$ & $385 \mathrm{~d}$ \\
\hline Simazine & 1.0 & 31 bcdef & $1230 \mathrm{~b}$ & $115 \mathrm{ab}$ \\
\hline Terbacil & 0.25 & $15 \mathrm{ab}$ & $635 a$ & $250 \mathrm{bcd}$ \\
\hline Terbacil & 0.5 & 42 efg & $1065 \mathrm{ab}$ & $70 a b$ \\
\hline
\end{tabular}

'Means in the same column followed by the same letter do not differ significantly at the $5 \%$ level by Duncan's multiple range test. control for this treatment was $86 \%$, but all other treatments were less than $60 \%$ effective the year after application.

Forage grass production was significantly increased only by the $1 \mathrm{lb} /$ acre rate of simazine when compared to the untreated plots. This treatment resulted in a forage grass yield increase of $686 \mathrm{lb} /$ acre or about $126 \%$. However, atrazine, cyanazine, metribuzin and terbacil at $0.5 \mathrm{lb} / \mathrm{acre}$, and metribuzin at 0.33 $\mathrm{lb} /$ acre increased forage grass yields more than $300 \mathrm{lb} / \mathrm{acre}$ when applied in the spring on a silt loam soil and evaluated the year after herbicide application. There were no significant forage grass yield increases from any treatment applied to a silt loam soil in the spring during the year of herbicide application. The year following herbicide application, downy brome production was reduced by atrazine at $1.0 \mathrm{lb} / \mathrm{acre}$, secbumeton at both rates, metribuzin at all rates, simazine at $1.0 \mathrm{lb} / \mathrm{acre}$, and cyanazine and terbacil at $0.5 \mathrm{lb} /$ acre. It appears that the most promising herbicide treatments in relation to control of downy brome and forage grass production to be applied to a silt loam soil in the spring would be atrazine at $0.5 \mathrm{lb} / \mathrm{acre}$ or simazine at $1.0 \mathrm{lb} /$ acre.

When herbicide treatments were applied in the spring on a silty clay soil, forage grass production was increased the yer of herbicide application by atrazine and terbacil at $0.5 \mathrm{lb} / \mathrm{acre}$ and cyanazine and metribuzin at $1.0 \mathrm{lb} /$ acre (Table 4$)$.

Table 4. Forage production (lb/acre, oven-dry) 5 months after spring application of herbicides on a silty clay loam soil of Nebraska rangeland. ${ }^{\prime}$

\begin{tabular}{lcc}
\hline \hline Herbicide & Rate $($ lb/acre $)$ & Forage production \\
\hline Check & - & $410 \mathrm{a}$ \\
Atrazine & 0.5 & $1305 \mathrm{~d}$ \\
Atrazine & 1.0 & $930 \mathrm{abcd}$ \\
Cyanazine & 0.5 & $905 \mathrm{abcd}$ \\
Cyanazine & 1.0 & $1010 \mathrm{~cd}$ \\
Glyphosate & 0.25 & $465 \mathrm{ab}$ \\
Glyphosate & 0.5 & $495 \mathrm{abc}$ \\
Secbumeton & 1.0 & $880 \mathrm{abcd}$ \\
Sechumenton & 2.0 & $860 \mathrm{abcd}$ \\
Metribuzin & 0.5 & $870 \mathrm{abcd}$ \\
Metribuzin & 1.0 & $1120 \mathrm{~d}$ \\
Paraquat & 0.25 & $540 \mathrm{abc}$ \\
Simazine & 0.5 & $920 \mathrm{abcd}$ \\
Simazine & 1.0 & $850 \mathrm{abcd}$ \\
Terbacil & 0.25 & $930 \mathrm{abcd}$ \\
Terbacil & 0.5 & $980 \mathrm{bcd}$
\end{tabular}

'Means followed by the same letter do not differ significantly at the $5 \%$ level by Duncan's multiple range test.

Forage yield increases when atrazine at $0.5 \mathrm{lb} /$ acre was applied in the spring and evaluated the same year was about 900 $\mathrm{lb} /$ acre. Cyanazine and metribuzin at $1.0 \mathrm{lb} /$ acre each increased forage production by about $600 \mathrm{lb} / \mathrm{acre}$, while the resulting increase from the application of terbacil at $0.5 \mathrm{lb} /$ acre was more than $550 \mathrm{lb} / \mathrm{acre}$.

Atrazine at 0.5 or $1.0 \mathrm{lb} /$ acre applied in the spring or fall to a variety of soils in areas of variable precipitation appears to be effective for the control of cool-season grassy weeds, such as downy brome, in grazing lands. Although no data are shown regarding injury to forage grasses, injury to forage grasses does appear to be greater from spring-applied herbicide treatments than from treatments applied in the fall. However, these forage grasses apparently are able to recover from this injury rapidly and with the reduced competition from the annual weeds, production will be increased. Proper grazing management must accompany weed control techniques for maximum benefits to be attained on a sustained basis. 


\section{Literature Cited}

Eckert, Richard E., Jr., Jerry E. Asher, M. Dale Christensen, and Raymond A. Evans. 1974. Evaluation of the atrazine-fallow technique for weed control and seedling establishment. J. Range Manage. 27:288-292. Evans, R. A., H. R. Holbo, R. E. Eckert, Jr., and J. A. Young. 1970. Functional environment of downy brome communities in relation to weed control and revegetation. Weed Sci. 18:154-162.

Hulbert, Lloyd C. 1955. Ecological studies of Bromus tectorum and other annual bromegrasses. Ecol. Monogr. 25:181-213.
Hull, A. C., Jr., and W. Theron Hansen, Jr. 1974. Delayed germination of cheatgrass seed. J. Range Manage. 27:366-368.

Kapusta, George, and C. F. Strieker. 1975. Selective control of downy brome in alfalfa. Weed Sci. 23:202-206.

Rydrych, D. J. 1974. Competition between winter wheat and downy brome. Weed Sci. 22:211-214.

Stewart, George, and A. C. Hull. 1949. Cheatgrass (Bromus tectorum L.)An ecologic intruder in southern Idaho. Ecology 30:58-74.

Young, J. A., R. A. Evans, and R. E. Eckert, Jr. 1969. Population dynamics of downy brome. Weed Sci. 17:20-26. 